\title{
Productivity and blood composition indicators of ram lambs during fattening with the use of oil-plant seeds in diets
}

\author{
A.T. Varakin ${ }^{1}$, D.K. Kulik ${ }^{2}$, V.S. Zoteev ${ }^{3, *}$, G.A. Simonov ${ }^{4}$, and O.V. Golovatyuk ${ }^{2}$ \\ ${ }^{1}$ Volgograd State Agrarian University, 400131 Volgograd, Russia \\ ${ }^{2}$ All-Russian Research Institute of Irrigated Agriculture, 472755 Volgograd, Russia \\ ${ }^{3}$ Samara State Agrarian University, 443001 Samara, Russia \\ ${ }^{4}$ Vologda Research Center of the Russian Academy of Sciences, North-Western Research Institute of \\ Dairy and Grassland Farming, 160555 Vologda, Russia
}

\begin{abstract}
The objective of the research was to study the effectiveness of inclusion of Camelina cake, which belongs to low-glucosinolate varieties, in the diets instead of sunflower cake on the productivity of fattened ram lambs. According to the results of a laboratory study, compared with sunflower cake, Camelina cake had a higher content of dry and organic matter, "crude" fat, "crude" fiber, nitrogen-free extractives, and there were practically no differences in "crude" protein. Scientific and economic experience was organized with the use of ram lambs of the Volgogradskaya breed. Physiological studies were carried out in conjunction with the scientific and economic experience with the use of animals in this experiment. At the end of the experiment, at the age of 8 months, the ram lambs of the experimental group, using Camelina seed cake in the main diet, had a higher average live weight by $1.43 \%$ than in the control, when using sunflower cake in the diet. In physiological studies, it was found that the animals in the experimental group digested and used the nutrients of the diet better than the young animals from the control group. Blood counts of both groups of ram lambs were normal. Control slaughter of sheep, conducted on the basis of research, showed that on average in the experimental group, the weight indicators increased: pre-slaughter, hot carcass, internal fat, slaughter, and slaughter yield, respectively, by $1.52 ; 1.69 ; 2.63 ; 1.74$ and $0.10 \%$ than in the control. In terms of profitability, fattening animals in the experimental group was $7.8 \%$ more efficient than in the control group.
\end{abstract}

\section{Introduction}

To further increase the efficiency of obtaining products in animal husbandry, it is necessary to expand the range of feeds and additives, the use of which makes it possible to more fully realize the genetically determined productive qualities of farm animals and contributes to the improvement of production indicators $[15,16,19]$.

\footnotetext{
*Corresponding author: gennadiy0007@mail.ru
} 
To solve this important problem at enterprises, it is possible to increase the productivity of animals by improving the quality of the diets used, their diversity in components composition, which serves to ensure the biological usefulness of feeding $[1,5,10$, $11]$.

Together with other nutrients, when organizing animal feeding, much attention is paid to providing their diets with protein $[8,20]$ and its qualitative composition [6]. In particular, the importance is attached to the protein nutritional value of diets in sheep [7].

Different feeds and supplements are used to balance protein diets of farm animals. Effective application of mustard feed concentrate "Gorlinka" [2], flax cake [ 14] and others was found. By-products that are processed into oil-plant oil by pressing - cake are affordable and valuable organic animal feed. The use of these feeds contributes to the replenishment of protein in the diet in case of its lack; improving the productive qualities of animals and, which is very important, ultimately, the efficiency of obtaining livestock products.

Therefore, the use of previously insufficiently used feed products that have great potential in energy value and protein, its quality, for example, certain types of cakes, is of a rather high interest for scientists and in economic activities in agro-industrial enterprises. In addition, they have high fat content. In general, cake has high nutritional value. When drawing up diets, their optimal amount for animals is taken into account.

The high-value waste obtained in the production of oil by pressing from the seeds of the spring crop of Camelina cake, which can serve as a high-protein feed additive for animals. However, some types of cake obtained from cruciferous seeds contain an increased amount of glucosides. Therefore, despite the high advantages in the composition of such cakes, their feed value is low and they require preliminary moisture and heat treatment to be used as feed. In this regard, Camelina of low-glucosinolate varieties was bred. This cake is also an important feed source for essential amino acids, such as lysine, methionine, tryptophan, and others that are not synthesized from other nitrogen-containing substances in the animal body.

As a valuable feed from Camelina seeds processing, cake has already found an effective application for balancing the diet of highly productive dairy goats [9].

It should be noted that the economic component also plays an important role in obtaining livestock products $[4,14,18]$.

Taking into account the above data, it is important and very relevant to study the use of Camelina cake, which belongs to low-glucosinolate varieties, in the technology of production of sheep products.

The purpose of our study is to study the productivity and blood composition indicators of ram lambs during fattening with the use of Camelina cake, which belongs to lowglucosinolate varieties, in diets instead of sunflower cake.

The objectives of our study were to evaluate the chemical composition of the compared cakes: sunflower and Camelina seeds; changes in live weight during the growth of experimental sheep; their physiological parameters; slaughter qualities; and the economic efficiency of the experiment results.

\section{Materials and methods}

Studies in the laboratory on determination of chemical composition of the test cakes: sunflower and Camelina low-glucosinolate varieties were performed according to the generally accepted methods of zootechnical analysis of feed.

In the scientific and economic experiment, 50 sheep of the Volgogradskaya breed were selected, of which 2 groups were formed in equal numbers of animals. Selection of sheep in groups was carried out using a method that takes into account the principle of pairsanalogues. The selection of animals also took into account: age, live weight, fatness. When 
tested, the age of ram lambs was 3.5 months, and the average live weight of animals in the control group was 27.8 and in the experimental group $-27.6 \mathrm{~kg}$.

Research of animals in the scientific and economic experiment was carried out over a period of 135 days. The preliminary period of the experiment lasted ten days, where they checked the similarity of sheep formed in groups, with feeding them the main diet. During this period, sunflower cake was used as part of the diet for both groups. The transition period of the experiment lasted five days, where the ram lambs of the control group used sunflower cake as part of the main diet; the experimental group included Camelina cake in the main diet with gradual training and replacement of sunflower cake. The main period of the experiment lasted one hundred and twenty days and the animals of the control group were fed with sunflower cake as part of the main diet; the experimental group was fed with Camelina cake as part of the main diet instead of sunflower cake. During the experiment, the conditions for keeping all the ram lambs and caring for them were the same.

Control over changes in the live weight of ram lambs during growth was carried out by individual weighing them for two adjacent days at the age of 4, 6 and 8 months (before feeding in the morning). The results of weighting were used to calculate the average daily increase in live weight of sheep.

Physiological studies were performed simultaneously with scientific and economic experience using animals from this experiment, that is, against its background. At the same time, these studies included the study of the digestibility and use of nutrients in the diet of experimental sheep in groups. The physiological state of the sheep was monitored by taking blood from three animals from the group and determining indicators that characterize the morphological and biochemical composition.

Meat productivity was studied at the control slaughter of three ram lambs in groups with the age of eight months. Before that, we performed a starvation exposure of animals during the time without giving: feed - 24 hours and water - 12 hours.

The economic efficiency of using sunflower and Camelina cake in diets in a comparative aspect was calculated based on the actual costs of growing ram lambs during fattening.

\section{Results and discussion}

When studying the test cakes in laboratory tests, a lower total moisture content of $3.1 \%$ was found in Camelina seed cake compared to sunflower seed cake with a content of $9.8 \%$. The results of the qualitative composition of cake by chemical composition are given in (table $1)$.

Table 1. Data on the chemical composition of cake, $\%$

\begin{tabular}{|c|c|c|}
\hline \multirow{2}{*}{ Indicator } & \multicolumn{2}{|c|}{ Cake } \\
\cline { 2 - 3 } & sunflower & Camelina \\
\hline Dry matter & 90.2 & 40.3 \\
\hline "Crude" protein & 40.6 & 8.3 \\
\hline "Crude" fat & 7.8 & 13.0 \\
\hline "Crude" fiber & 12.9 & 25.4 \\
\hline Nitrogen-free extractive substances & 22.3 & \\
\hline
\end{tabular}

Data describing the qualitative composition of the tested feed by chemical composition indicate that the content of dry matter in the cake produced from Camelina seeds was $3.1 \%$ higher; "drude" fat - 0.5; "u" fiber - 0.1; nitrogen-free extractives - 3.1\% higher than in sunflower. Organic matter was contained in the analyzed feeds, respectively, 87.2 and 83.6 in favor of Camelina cake with a difference of $3.6 \%$. For "crude" protein, almost no significant differences were found between the tested feeds. 
Research on ram lambs in the scientific and economic experiment was organized in July-November during the pasture period. The use of feed and additives in the diet was guided by the feeding standards developed by the RAAS.

In the age period from 4 to 6 months, based on one animal, the main daily diet included: pasture - grass-mixed grass in the amount of $2.9 \mathrm{~kg}$, barley groats - $0.10 \mathrm{~kg}$ and necessary minerals as feed additives. At the same time, the control group included sunflower cake in the amount of $0.08 \mathrm{~kg}$ per animal in the diet; the experimental group - cake produced from Camelina seeds in the same amount.

In the age period from 6 to 8 months, based on one animal, the main daily diet included: pasture - grass-mixed grass in the amount of $3.7 \mathrm{~kg}$, barley groats - $0.14 \mathrm{~kg}$ and necessary minerals as feed additives. At the same time, the control group included sunflower cake in the amount of $0.07 \mathrm{~kg}$ per animal in the diet; the experimental group - cake produced from Camelina seeds in the same amount.

The results of comparative tests on the replacement of sunflower cake in the main diet with Camelina low-glucosinolate varieties showed that this did not negatively affect the live weight of experimental sheep during their growth and development at the age of 4 to 8 months. The data obtained in the comparative aspect for groups are shown in (table 2).

Table 2. Live weight in sheep during growth, $\mathrm{kg}(\mathrm{n}=25)(\mathrm{M} \pm \mathrm{m})$

\begin{tabular}{|c|c|c|}
\hline \multirow{2}{*}{ Anumals age } & \multicolumn{2}{|c|}{ Live weight of ram hogs } \\
\cline { 2 - 3 } & control group & experimental group \\
\hline Four months & $29.24 \pm 0.27$ & $29.04 \pm 0.25$ \\
\hline Six months & $37.22 \pm 0.19$ & $37.50 \pm 0.23$ \\
\hline Eight months & $44.60 \pm 0.32$ & $45.24 \pm 0.28$ \\
\hline
\end{tabular}

Assessin the fatness of young farm animals, researchers report that it has a relationship with live weight and productivity [17].

In our experiment, during the growth of experimental ram lambs, it was found that at the age of four months (the beginning of the main period of the experiment), the sheep of both groups did not have a significant difference in terms of the average live weight.

Further studies showed that at the age of six months, the sheep in the experimental group had an average live weight slightly higher, namely by $0.28 \mathrm{~kg}(0.75 \%)$ relative to the control group.

The study of the growth of experimental animals in groups later showed that there were even greater differences in the indicator of live weight with an advantage in the experimental group. Sheep of this group at the age of eight months had a live weight $0.64 \mathrm{~kg}$ $(1.43 \%)$ more than in the control group.

During the main period of this experiment in the experimental group, the average daily live weight gain per ram lamb increased by $7.0 \mathrm{~g}$ or $5.47 \%$, compared to the control group.

According to the results obtained, calculations were performed that showed that the consumption of energy feed units ( $1 \mathrm{EFU}=10 \mathrm{MJ}$ of exchange energy) for an increase of 1 $\mathrm{kg}$ of live weight of animals in the experimental group was less than in the control group. This is due to the higher productivity of fattened sheep, which were fed with diets with cake produced from Camelina seeds in the composition. During the experiment, no diseases were detected in the experimental sheep, as well as no refusal to consume feed. The population of ram lambs was preserved completely in groups.

When studying the effectiveness of feed factors in sheep breeding, researchers pay significant attention to determining the digestibility of feed nutrients [12], and nitrogen exchange in the body of sheep [3].

In a physiological experiment on the study of indicators that characterize the digestibility and use of nutrients in the diet of young sheep, groups found that the best result in ram 
lambs that consumed cake produced from camelina seeds. The animals of the experimental group had these indicators higher than in the compared control.

When feeding the test feeds, due attention is paid to the study of physiological parameters and resistance of the body of ram lambs in experiments [13]. Researchers also found a correlation between the consumption of feed by young growing cattle and blood composition indicators [21].

Describing the data of our results of the study of morphological and biochemical parameters of the blood of ram lambs by groups, it should be noted that they corresponded to the physiological norm (table 3).

Table 3. Data on hematological studies in sheep $(n=3)$

\begin{tabular}{|c|c|c|}
\hline \multirow{2}{*}{ Indicator } & \multicolumn{2}{|c|}{ Group } \\
\cline { 2 - 3 } & control & experimental \\
\hline $\begin{array}{c}\text { Content in whole blood: } \\
\text { red blood cells, } 10^{12} / 1\end{array}$ & $9.05 \pm 0.06$ & $9.08 \pm 0.04$ \\
\hline white blood cells, $10^{9} / 1$ & $8.60 \pm 0.03$ & $8.65 \pm 0.06$ \\
\hline hemoglobin, g/1 & $94.74 \pm 0.50$ & $94.80 \pm 0.53$ \\
\hline $\begin{array}{c}\text { Contained in blood serum: } \\
\text { total protein, g/1 }\end{array}$ & $67.28 \pm 0.21$ & $67.69 \pm 0.19$ \\
\hline
\end{tabular}

The results also showed that the number of red blood cells in the experimental group at the age of eight months was higher than in the control group by $0.03 \times 10^{12} / 1(0.33 \%)$. According to the concentration of hemoglobin in the blood, the advantage of animals that were fed as part of the diet cake produced from camelina seeds was $0.06 \mathrm{~g} / 1$ or $0.06 \%$.

Blood composition indicators also correlate with signs of growth in young animals [22].

Thus, in young sheep aged 8 months in the experimental group, the total protein content in the blood serum was higher than in animals in the control group by $0.41 \mathrm{~g} / 1(0.61 \%)$.

According to our results of the study on hematological indicators of animals by groups, there was an increase in the level of metabolism in the body of sheep, which in the main diet were fed with cake produced from seeds of camelina low-glucosinolate varieties, instead of cake obtained during processing of sunflower seeds. As a result, more intensive growth of ram lambs was found in the experimental group than in the animals of the control group.

The ram lambs reached the age of eight months and a control slaughter was organized. The results that characterize the meat productivity of sheep during fattening are shown in (table 4).

Table 4. Quantitative indicators of meat qualities of sheep during fattening, $\mathrm{kg}(\mathrm{n}=3)$

\begin{tabular}{|c|c|c|}
\hline \multirow{2}{*}{ Indicator } & \multicolumn{2}{|c|}{ Group } \\
\cline { 2 - 3 } & control & experimental \\
\hline Sheep weight before slaughter & $43.30 \pm 0.37$ & $43.96 \pm 0.31$ \\
\hline Hot carcass weight & $18.39 \pm 0.24$ & $18.70 \pm 0.19$ \\
\hline Internal fat weight & $1.14 \pm 0.02$ & $1.17 \pm 0.03$ \\
\hline Slaughter weight & $19.53 \pm 0.25$ & $19.87 \pm 0.22$ \\
\hline
\end{tabular}

In terms of quantitative indicators of meat qualities, ram lambs that were fed with cake produced from camelina ginger seeds in the diet had an advantage over animals when sunflower cake was introduced into the diet. Thus, on average, the live weight index of sheep in the experimental group before slaughter was higher than in the control group by $1.52 \%$. The carcass weight and development of internal fat tissue of the experimental group of ram lambs were at an advantage, compared to the control group of sheep, by 1.69 and $2.63 \%$, respectively. 
According to such an important indicator as the slaughter weight, in comparison with the control, the advantage of ram lambs that were fed with camelina seeds cake as a part of the diet was $1.74 \%$.

In studies of the productivity of fattened animals, yield indicators for their meat qualities occupy an important place and are of considerable interest (table 5).

Table 5. Yield indicators for meat qualities of sheep during fattening, $\%(n=3)$

\begin{tabular}{|c|c|c|}
\hline \multirow{2}{*}{ Indicator } & \multicolumn{2}{|c|}{ Group } \\
\cline { 2 - 3 } & control & experimental \\
\hline Hot carcass yield & 42.47 & 42.54 \\
\hline Internal fat yield & 2.63 & 2.66 \\
\hline Slaughter yield & 45.10 & 45.20 \\
\hline
\end{tabular}

The animals of the experimental group also had higher indicators for the carcass and internal fat yield.

According to a very significant indicator, as a slaughter yield, relative to control animals, the advantage of ram lambs, which were fed with camelina seeds cake as part of the diet, was $0.10 \%$.

The data presented in our study indicate that the organization of fattening of sheep up to eight months of age allows to raise animals with sufficient live weight, and with a high yield of meat products. However, the highest meat qualities were found in the experimental group of ram lambs when they were fed camelina cake in the main diet instead of sunflower cake.

Calculations that characterize the economic efficiency of the results of the study were performed at the end of the scientific and economic experiment When organizing the experiment, the price for purchasing sunflower and camelina cake was the same. According to the results of calculations, the cost of $1 \mathrm{~kg}$ of live weight gain of ram lambs in the experimental group was less, and the profit per animal was higher relative to the control group. The indicator of profitability level of sheep during fattening in the experimental group was $49.9 \%$, with an advantage of $7.8 \%$ relative to the control.

Thus, in the production of lamb and increasing economic efficiency, along with the introduction of cake produced from sunflower seeds, it is also advisable to use camelina cake in the diets of young sheep when fattening.

\section{Conclusions}

Qualitative indicators of the chemical composition of ginger cake of low-glucosinolate varieties were higher than sunflower cake, namely, the following indicators: dry and organic matter, respectively, by 3.1 and $3.6 \%$, " raw " fat-by $0.5 \%$," raw "fiber - by $0.1 \%$, nitrogen - free extractive substances-by $3.1 \%$, and compared cakes did not differ significantly by "crude" protein.

Introduction of cake produced from low-glucosinolate varieties of camelina seeds into the diet had a positive effect on the change in live weight during the growth of sheep, the digestibility and use of feed nutrients in young animals in the experimental group, compared with the use of sunflower cake for animals in the control group. Control of morphological and biochemical parameters of the blood of ram lambs in groups showed their compliance with the physiological norm.

The use of camelina cake of low-glucosinolate varieties in the diets of rams in the experimental group instead of sunflower cake, as in the control group, made it possible to increase the average pre-slaughter live weight and the weight of the hot carcass by 1.52 and $1.69 \%$, respectively, and the internal fat weight by $2.63 \%$, as well as slaughter weight and 
slaughter yield by 1.74 and $0.10 \%$. The advantage of sheep in the experimental group was also revealed in terms of carcass yield and internal fat yield.

The best efficiency of lamb production was established when using camelina seeds cake in the diets of sheep of the Volgogradskaya breed, with the replacement of sunflower cake. The cost of $1 \mathrm{~kg}$ of live weight gain of sheep in the experimental group was less, and the average profit per sheep was more than in the control group. The level of profitability when fattening sheep in the experimental group was higher by $7.8 \%$ compared to the animals in the control group.

\section{References}

1. V.P. Lushnikov, A.S. Filatov, B.N. Sharlapaev, E.I. Likhacheva, Zootechny, 4, 14-15 (2006)

2. S.I. Nikolaev, Proceedings of Nuzhnevolzhsky Agrouniversity complex: science and higher professional education, 4(48), 205-212 (2017)

3. V.I. Kosilov, S.R. Ziyangirova, I.V. Mironova, Sheep, goats, wool business, 2, 45-46 (2019)

4. D.K. Kulik, A.T. Varakin, V.V. Salomatin, E. A. Kharlamova, Effect of feed additives on the productive indicators of ram lambs, Ecological and meliorative aspects of rational nature management: materials of the International Scientific and Practical Conference (Volgograd: FSNEI HE Volgograd SAU) 4, 259-264 (2017)

5. D.B. Mandzhiev [et al.], Sheep, goats, wool business, 2, 47-48 (2019)

6. V.K. Gurin, V.F. Radchikov, V.I. Karpovsky, Zootechnical science of Belarus: collection of scientific papers. Zhodino, 51,1, 257-266 (2016)

7. V.G. Dvalishvili, ARIB, 53, 80-88 (1989)

8. A.I. Denkin, V.O. Lemeshevsky, Agrarian Bulletin of the Urals, 08(199), 34-42 (2020)

9. V.S. Zoteev, G.A. Simonov, G.B. Kuznetsov, Sheep, goats, wool business, 3, 29-30 (2014)

10. A.P. Kalashnikov [et al.], Animal Husbandry, 9, 7-8 (1984)

11. A.P. Kalashnikov [et al.], Russian agricultural science, 11, 29-30 (1984)

12. A. Ushakov, V. Epifanov, A. Mikityuk [et al.], Compound Feed, 12, 81-82 (2016)

13. N.G. Chamurliev, A.S. Filatov, A.S. Shperov [et. al.], Proceedings of Nizhnevolzhsky Agrouniversity complex: science and higher professional education, 3(51), 247-251 (2018)

14. A.T. Varakin, V.V. Salomatin, E.A. Kharlamova, T.A. Varlamova, Proceedings of the Samara Фtate agricultural Academy, 3, 30-34 (2018)

15. V.S. Zoteev, L. Ilyukhina, G.A. Simonov, Animal Husbandry, 5, 45-46 (1985)

16. G. Simonov, S. Tapugin, D. Gayirbegov [et. al.], Dairy and beef cattle, 4, 19-21 (2011)

17. I.N. Khakimov, Kh.B. Baimishev, V.V. Salomatin, S.I. Nikolaev, D.A. Randelin, A.L. Akimov, Journal of Fundamental and Applied Sciences, 10(7S), 337-349 (2018)

18. A.M. Uhtverov, Kh.B. Baymishev, I.N. Khakimov, M.A. Kohanov, V.S. Grigoryev, A.T. Varakin, Research Journal of Pharmaceutical, Biological and Chemical Sciences, 9(5), 935-942 (2018)

19. V.S. Zoteev, E. I. Pisarev, S.I. Nikolaev, V.V. Salomatin, A.T. Varakin, Research Journal of Pharmaceutical, Biological and Chemical Sciences, 9(5), 1422-1428 (2018)

20. G.R. Fenwick, Proc. Nutr. Soc., 41, 277-288 (1982) 
21. C.F. Nascimento, R.H. Branco, S.F. Bonilha, J.N. Cyrillo, J.A. Negrão, M.E. Mercadante, Journal of Animal Science, 93(3), 1318-1326 (2015)

22. C.A. Lents, L.A. Rempel, J. Klindt, T. Wise, D. Nonneman, B.A. Freking, Journal of Animal Science, 91(7), 3137-3142 (2013) 